\title{
15 Temmuz Darbe Girişimi Sonrası 'Demokrasi Nöbetlerinin’ Halkla İlişkiler ve Kamuoyu Açısından Değerlendirilmesi
}

\section{The Evaluation of 'Democracy Watchs' after 15 July Coup Attempt Initiatives from Public Relations and the Public Opinion}

\author{
Nural İmik Tanyıldızı, ${ }^{a, *}$ Taha Yasin Ateş ${ }^{b}$ \\ ${ }^{a}$ Doç. Dr., Fırat Üniversitesi, İletişim Fakültesi, Halkla İlişkiler ve Tanıtım Bölümü, 23119, Elazığ/Türkiye. \\ ORCID: 0000-0002-9177-759X \\ b Öğr. Gör., İnönü Üniversitesi, Battalgazi Meslek Yüksek Okulu, Yerel Yönetimler Bölümü, 44210, Malatya/Türkiye. \\ ORCID: 0000-0003-4310-8014
}

\section{MAKALE BILGİSI}

\section{Makale Geçmişi:}

Başvuru tarihi: 19 Eylül 2017

Düzeltme tarihi: 04 Ekim 2017

Kabul tarihi: 07 Kasım 2017

\section{Anahtar Kelimeler:}

Siyasal İletişim

Kamuoyu

Demokrasi Nöbetleri

Mitingler

\section{ARTICLE INFO}

\section{Article history:}

Received 19 September 2017

Received in revised form 04 October 2017

Accepted 07 November 2017

\section{Keywords:}

Political Communication

Public Opinion

Democracy Seizures

Meetings

\section{ÖZ}

Siyasal iletişimde kamuoyu oluşturmak için yapılan çalışmalar sadece seçim dönemlerinde değil, ülkede önemli olayların yaşandığı zamanlarda da kullanılmaktadır. Bu çalışmada 15 Temmuz darbe girişimine karşı düzenlenen ve "Demokrasi Nöbetleri" olarak isimlendirilen, bir ay kadar devam eden sürecin toplum üzerindeki etkileri halkla ilişkiler ve kamuoyu açısından ele alınmaktadır. $\mathrm{Bu}$ süreçte yöneticiler ve özellikle iktidar siyasal iletişim yöntemleri ile 'Demokrasi Nöbetleri' üzerinden bir kampanya yürütmüştür. Araştırmanın amacına ulaşması için Malatya il merkezinde bulunan 500 kişiye anket uygulanmış ve bu teknik ile elde edilen veriler bilgisayar ortamında SPSS programı yardımı ile analiz edilmiștir. Analizlerde halkın sokağa çıkmasını tetikleyen sebepler ve daha sonra oluşan/oluşturulan kamuoyu ve algı elde edilen veriler ile ortaya konulmaya çalışılmıştır.

\begin{abstract}
A B S T R A C T
The work done to create the public opinion in political communication is not only used during election periods, but also when important events happen in the country. In this study, the effects on the society which are organized against the 15 July coup attempt and termed as "democracy bouts" and lasting for about one month are considered from the point of view of the public and the public. In this process, the executives and especially the government conducted a campaign through 'democracy bouts' with the methods of political communication. A questionnaire was applied to 500 people in Malatya province center and the data obtained with this technique were analyzed with the help of SPSS program in computer environment. In the analyzes, the reasons that triggered the people to go out on the streets and the public opinion that was formed / created later and the perceived data were tried to be revealed.
\end{abstract}

\section{Giriş}

Kitle iletişim araçlarının gelişmesi ve buna bağlı olarak enformasyonun hıla yayılması halkın düşünceleri ve yönetimden beklentilerini daha da önemli hale getirmiştir. İletişim araçlarında yaşanan yeniliklerle toplumları harekete geçirmek ve bu toplumsal hareketler vasitasıyla genel bir alg1 oluşturmak daha kolay hale gelmiştir. Siyasette de s1klıkla kullanılan bu durum sayesinde toplumları bir arada tutup hareket ettirmek mümkündür. Halkla ilişkiler özellikle de siyasal halkla ilişkiler kamunun dikkatini belirli konulara çekmek için yapılmaktadır. Yıllardır süren siyasal halkla ilişkiler araştırmalarının çoğu haber medyasında konu seçimi, üretimi ve bu yolla halkın dikkatini çekme üzerine yoğunlaşmıştır. Bununla birlikte siyasal halkla ilişkilerin temel hedefi halkın desteğini kazanmak umuduyla yapılan

\footnotetext{
* Sorumlu yazar/Corresponding author.
} e-posta: nimik@ firat.edu.tr 
çalışmalar ve kampanyalarla siyasilerin görüş, çözüm ve yorumlarını hedef kitleye iletmektir (Froehlich ve Rudiger, 2006: 18).

Halkla ilişkilerde kullanılan araçlarla hedef kitleyi etkilemek ile ilgili yurt dışında ve yurt içinde bir çok araştırma yapılmıştır (Weaver ve Glasser, 1984; Harris vd., 1985; Greyser, 1986; Petrison ve Wang, 1993; Ramsey, 1993; Page ve Adams, 2014; Verčič vd., 2015; Toledano, 2017, Özüpek, 2003; Atik ve Taşcıŏglu, 2009; Onat, 2010; Demir, 2011; Bayer, 2009). $\mathrm{Bu}$ örnekleri artırmak mümkündür. $\mathrm{Bu}$ araştırmada ise toplantı ve mitingler içerisinde değerlendirilecek olan "Demokrasi Nöbetleri" halkla ilişkilerde kullanılan araçlardan biri olarak ele alınmıştır. 15 Temmuz darbe girişimi sonrasında tutulan Demokrasi Nöbetlerinin kamuoyunu ne yönde etkilediğini halkla ilişkiler açısından ortaya koymak amaçlanmıştır. Araştırmanın diğer araştırmalardan en önemli farkı ise Türkiye'de 15 Temmuz 2016 tarihinde yaşanmış olan darbe girişimi sonrasında ortaya çıkan "Demokrasi Nöbetleri” nin halkla ilişkiler ve kamuoyu oluşturma açısından bir değerlendirmesini yapmasıdır. Araştırma konusu ile doğrudan ilgili Ankara Sosyal Bilimler Üniversitesinin 2016 yılında yapmış olduğu "Demokrasi Nöbetlerine Katılanlar Hakkında Sosyolojik Bir Araştırma" başlıklı rapora (https://www.asbu.edu.tr) ve KONDA'nın yapmış olduğu Demokrasi Nöbetlerine katılanların profili ile ilgili araştırmaya ulaşılmıştır (http://bianet.org). Araştırmanın amacına ulaşması için Alan Araştırması modeli uygulanmış ve bu doğrultuda anket tekniğine başvurulmuştur. Araştırma Malatya il merkezinde ( Battalgazi ve Yeşilyurt'tan oluşan iki merkez ilçede ) bulunan 500 kişi ile sınırlı tutulmuştur. $\mathrm{Bu}$ teknik ile elde edilen veriler bilgisayar ortamında SPSS programı yardımı ile analiz edilmiştir.

\section{Siyasal Halkla İlişkiler}

Halkla ilişkiler 20.yüzyılın bir olgusu olarak görülmekle birlikte gerçekte tarihin çok eski dönemlerine kadar uzanan bir geçmişe sahiptir. Halkla ilişkiler kelimesi kullanılmadan eski Yunan, Roma, Mısır gibi birçok medeniyet kamuoyu oluşturmak, uygulanan kuralları pekiştirmek ve halkın gözünde sürekliliklerini sağlamak için halkla ilişkiler tekniklerinden yararlanmışlardır (Peltekoğlu, 2001: 66). Kısacası araçları farklı olsa da halkla ilişkiler olgusu geçmişten bu yana var olmuştur. $\mathrm{Bu}$ denli eski tarihlere dayanması halkla ilişkiler konusunun öneminin de bir göstergesidir.

Kamuoyunu ikna yoluyla etkilemenin önemini tarihteki tüm liderler fark etmiştir. Bunun nedeni, kamuoyunun her dönemde yönetimin dikkate almak zorunda olduğu bir güç olmasıdır (Çağlar, 2006: 12). Siyaset bilimciler kamuoyunu tanımlamaya çalışırken kanaatlerin toplanması veya açığa çıkması olayını, seçimler, seçim sonuçları ya da kamu siyasasının çoğunluğunun isteği doğrultusunda belirlenmesi ile açıklamaktadır. Ayrıca siyasette kamuoyu karşılıklı ilişki ve etkileşim sürecinden oluşmaktadır. Siyasetçilerde alacakları kararlarda kamuoyunun düşüncesini göz önünde bulundurmalılardır. Dolayısı ile demokratik rejimin işlediği varsayıldığında kamuoyu, kamu siyasasının belirlenmesi ve oluşumu açısından büyük önem taşımaktadır (Bektaş, 2007; 56-57). Halkla ilişkiler, yönetimin, kamuoyunun görüşleri hakkında bilgilendirilmesi ve yetkin olmasını içermektedir. Hem hedef kitlenin beklenen eğilimini erkenden anlamaya yardımcı olarak yararlı değişimlere uyum sağlamayı kolaylaştırır hem de araştırmayı ve iletişim tekniklerini temel amaç edinmektedir (Peltekoğlu, 2001: 6).

Siyasette de seçmenlerin belirgin biçimde yapılan yönlendirme çalışmalarından olumsuz etkilenmesi ve bunlara direnç göstermesi siyasetçileri seçmene daha tarafsız gelecek, objektif ve tutarlı başka yöntemleri uygulamaya yöneltmiştir. Artık siyasal reklam ve propagandadan başka yöntemler de kullanılmaya başlanmıştır. Bu yöntemlerin en önemlisi siyasal halkla ilişkilerdir (Süllü, 2010: 221). Halkla ilişkiler programlarından biri olan siyasal halkla ilişkiler medya ve halkla iletişim kurmak için yavaş yavaş stratejiler geliştirmiştir. Medya yönetimi ve bilgi yönetimi, siyasal halkla ilişkilerin en önemli faaliyetleridir (Tomić ve Grbavac, 2016: 84). Siyasal halkla ilişkiler siyasi bir aktör veya organizasyonun misyonunu desteklemek, itibar oluşturmak hedef kitleleriyle yararlı ilişkiler kurmak, , inşa etmek ve sürdürmek için yapılan amaçlı iletişimdir (Strömbäck ve Kiousis, 2011; 25). Gündem oluşturma ve gündem belirleme teorileri seçimlerde ve halkı yönetime katmada siyasal halkla ilişkiler faaliyetlerinin rolünü anlamada kavramsal bir çerçeve sunmaktadır (Kiousis vd. 2014: 615). Siyasette kullanılan halkla ilişkiler faaliyetleri ile seçmenlere daha tarafsız gelecek yönlendirmelerin yapılması mümkündür.

\section{Siyasal Halkla İlişkilerde Toplantı ve Mitinglerin Rolü}

Kitle psikolojisini doğru belirleyebilmek seçim dönemlerinde önemli hale gelmektedir. Halkın tutumlarını ve kanaatleri doğru yönde tespit edebilmek, halkla süreğen bir diyalog ortamı; kahvehane buluşmaları, parti kongreleri ve mitingler gibi kitlelerle bir arada iletişim kurma olanaklarıyla mümkün olabilmektedir (Ustakara, 2011: 179). Son yıllarda çevrimiçi platformlar özellikle sosyal medya seçmenlerle iletişim kurmada diyalog ve kendini ifadeye yer vermesi açısından etkili iletişim kanallarıdır. Çevirim içi platformlardan yürütülen siyasal kampanyalar yalnızca vatandaş ve aday arasında güçlü ilişkiler kurmaz ayrıca siyasi sistemi de güvence altına alabilir (Painter, 2015: 807). Günümüzde her ne kadar siyasal halkla ilişkilerde yaygınlaşmaya başlayan çevirim içi platformlar olsa da yüz yüze yapılan iletişim şekilleri siyasal halkla ilişkilerde yaygın ve yoğun bir biçimde kullanılmaya devam etmektedir.

Siyasette kullanılan yüz yüze iletişim şekillerinde parti adaylarının veya aday adına özel görevlilerin, mahalle, köy, sokak veya evleri dolaşarak seçmenlere partilerinin görüşlerini anlatması söz konusudur. Seçmenle bire bir ilişki kurulan, daha samimi ve geri beslenmenin anında alındığ 1 bir iletişim biçimidir. En önemli özelliği seçmeni ikna etme olasılığının yüksek olmasıdır (Kalçık, 2007: 143). Seçmenle doğrudan buluşmaları içeren yüz yüze iletişim şekilleri özellikle fazla bütçesi olmayan parti ve adaylar için daha çok önem taşıyabilir. Çünkü bu parti ve adaylar maddi imkansızlıklar nedeniyle gerçekleştiremediği bir takım çalışmaları ve projeleri gönüllü gruplarla gerçekleştirme imkanı bulmaktadır (Devran, 2004: 212).

Siyasal halkla ilişkilerde kullanılan yüz yüze iletişim biçimlerinde politikacılar ve seçmenler bir etkileşim içerisine girmektedir. Kişi hem iletişim göndericisi hem de 
alıcısı olduğu için, bu etkileşim kaçınılmazdır. İletişim gerek sözlü gerekse sözlü olmayan yöntemlerle gerçekleşmekte, taraflar bir birlerini, diğer hiçbir yöntemde yaşayamayacakları oranda tanıma firsatı bulmaktadır. Siyasetçilerin doğal ortamda söyledikleri sözler, yüz ve göz ifadeleri, el hareketleri, duruş tarzları ve diğer sözel ve sözel olmayan belirtiler, onun samimiyeti, dürüstlüğü ve kişiliği hakkında önemli göstergelerdir (Oktay, 2002: 218-219). Mitingler veya büyük halk toplantıları, parti liderlerinin veya adaylarının, seçmen kitlesiyle kişisel iletişim ortamı kurmak ve seçmenlere gündemdeki sorunlarına bakış açılarını, vaatlerini ve ideolojilerini açıklamak aç ısından önemlidir (Kalçık, 2007: 143). Türkiye'de mitingler hala bir seçim kampanyasının en önemli araçlarındandır. İyi hazırlanılmış bir mitingin seçimin kazanılıp ya da kaybedileceğinin ipuçlarını vermesi mümkündür. Mitinglerde ne kadar çok bayrak, döviz, afiş kullanılırsa, rakiplere nazaran ne kadar güçlü olunduğu gösterilecektir. Çünkü her el kaldıranın sizin seçmeniniz olduğu ve çok güçlü olduğunuz yolunda bir kanaat uyanmaktadır (Demirtaş, 2010: 108). Mitinglerin seçmen üzerinde istenilen etkiyi sağlayabilmesi, mitingin düzenlenmesi ile yaratılacak atmosfere ve yapılacak olan konuşmaya bağlıdır. Mitinglerde ses düzeni, görsel tasarım, ünlü ya da tanınmış kişilerin lider ya da adaylarla birlikte kürsüde bulunması seçmenlerin karar ve tutumlarını etkilemektedir (Uztuğ, 2004: 299). Kısacası siyasal halkla ilişkilerde kullanılan yüz yüze organizasyonların içinde yer alan toplant, miting ve buna benzer faaliyetlerin bire bir ilişki kurulan, daha samimi ve geri beslenmenin anında alındığı iletişim biçimleri olması nedeniyle toplum üzerinde etkisinin yüksek olduğunu söylemek mümkündür.

\section{15 Temmuz Darbe Girişimi Sonrası Demokrasi Nöbetlerinin Etkilerine Yönelik Bir Araştırma}

\subsection{Araştırmanın Amacı ve Önemi}

Bu çalışmanın amacı; 15 Temmuz darbe girişimi sonrasında tutulan Demokrasi Nöbetlerinin kamuoyunu ne yönde etkilediğini halkla ilişkiler açısından ortaya koymaktır. Araştırma, darbe girişimi sonrası yapılması ve tutulan nöbetlerin Türkiye'de bir ilk olması açısından büyük önem arz etmektedir.

\subsection{Araştırmanın Hipotezi}

Araştırmada 15 Temmuz darbe girişimi sonrasında yapılan Demokrasi Nöbetlerinin halkı ortak noktalarda birleştirerek darbeye karşı bir kamuoyu oluşturduğu, yöneten ve yönetilenler arasındaki iletişimi güçlendirerek, yurt içinde ve yurt dışında birlik ve beraberlik mesajı verildiği hipotezinden hareket edilmiştir.

\subsection{Araştırmanın Örneklemi ve Yöntemi}

Araştırmanın amacına ulaşması için Alan Araştırması modeli uygulanmış ve bu doğrultuda anket tekniğine başvurulmuştur. Anket tekniğinde 75 bin kişi ile 1 milyon nüfuslu yerleşim yerleri için anketin en az 384 kişiye uygulanması gerekmektedir ( Krejcie and Morgan, 1970: 607-610). Bu nedenle Araştırma Malatya il merkezinde (Battalgazi ve Yeşilyurt'tan oluşan iki merkez ilçede) bulunan 500 kişi ile sınırlıdır. 18 yaş altı kişiler seçmen olamayacakları için araştırma dışında tutulmuştur. Olasılıklı örnekleme yöntemlerinden biri olan basit rastgele örnekleme yöntemi seçilmiştir. Toplam 13 sorudan oluşan anket formu kullanılmıştır ve anket araştırmanın amaçları doğrultusunda oluşturulmuştur. İlk olarak 20 kişilik kontrol grubunda denenen anket formu, gerekli düzeltmeler ve eklemelerden sonra uygulamaya konulmuştur. Araştırmada elde edilen veriler bilgisayar ortamına aktarılarak frekans ve yüzde analizleri yapılmıştır. Anketin güvenilirliği Cronbach Alpha katsayısı ile hesaplanmış ve güvenilir olduğu belirlenmiştir.

\subsection{Verilerin Toplanmas 1}

Hazırlanan anket formunda, ankete katılanların yaşlarının, cinsiyetlerinin, eğitim durumlarının ve mesleklerinin sorulduğu kişisel bilgiler bölümünün sonrasında özellikle 15 Temmuz darbe girişimi gecesi ve sonrasında yaşanan Demokrasi Nöbetlerinin etkilerini tespit etmek amacıyla hazırlanan sorular bulunmaktadır. Anket çalışması ile toplanan veriler, SPSS 20.0 istatistik programı ile değerlendirilerek verilen cevapların frekans ve yüzde değerleri bulunmuştur.

\section{Bulgular}

$\mathrm{Bu}$ başlık altında verilen bilgiler öncelikle tablo ile gösterilmiş daha sonrada açıklamaları yapılmıştır.

Tablo 1. Ankete Katılanların Yaşa Göre Dağılımı

\begin{tabular}{|c|c|c|}
\hline & Frekans & $\%$ \\
\hline $18-25$ aras1 & 109 & 21,4 \\
\hline $26-35$ aras1 & 120 & 24 \\
\hline 36-45aras1 & 94 & 19 \\
\hline $46-55$ aras1 & 103 & 21 \\
\hline 55 yaş üstü & 74 & 14,06 \\
\hline Toplam & 500 & 100 \\
\hline
\end{tabular}
incelendiğinde \%21,4 ünün 18-25 yaş aralığında, \%24 ünün 26-35 yaş aralığında, \%19'unun 36-45 yaş aralığında, \%21'inin 46-55 yaş aralığında ve \%14,06 sının da 55 yaş ve üstü olduğu görülmüştür.

Tablo 2. Ankete Katılanların Cinsiyetlerine Göre Dağılımı

\begin{tabular}{lcc}
\hline & Frekans & $\%$ \\
\hline Kadın & 218 & 44 \\
Erkek & 282 & 56 \\
\hline Toplam & 500 & 100 \\
\hline
\end{tabular}

Araştırmaya katılan 500 kişinin \% 44 ü kadın, \%56'sı da erkektir.

Tablo 3. Ankete Katılanların Eğitim Durumlarına Göre Dağılımı

\begin{tabular}{lcc}
\hline & Frekans & $\%$ \\
\hline Okur-Yazar değil & 29 & 5,8 \\
İlkokul & 90 & 18 \\
Ortaokul & 85 & 17 \\
Lise & 173 & 35 \\
Ön Lisans & 65 & 13,2 \\
Lisans & 58 & 11 \\
\hline Toplam & 500 & 100 \\
\hline
\end{tabular}

Araştırmaya katılanların \%18'inin ilkokul, \% 17'sinin ortaokul, \% 35'inin lise, \%13,2'sinin ön lisans, \% 11'inin de lisans seviyesinde üniversite mezunu oldukları görülmektedir. Ayrıca katılımcıların \% 5,8'i ise okuma yazma bilmemektedir. 
Tablo 4. Ankete Katılanların Mesleklerine Göre Dağılım

\begin{tabular}{lcc}
\hline & Frekans & $\%$ \\
\hline Kamu Görevlisi & 48 & 10 \\
Emekli & 53 & 11 \\
İşçi & 60 & 12 \\
Çiftçi & 16 & 3 \\
Öğrenci & 44 & 9 \\
Esnaf & 101 & 20 \\
Ev Hanımı & 126 & 25 \\
Serbest Meslek & 52 & 10 \\
\hline Toplam & 500 & 100 \\
\hline
\end{tabular}

Katılımcıların mesleklerine bakıldığında \%10’unun kamu görelisi, \%11'inin emekli, \%12'sinin işçi, \% 3'ünün çiftçi, \%9'unun öğrenci, \%20'sinin esnaf, \% 25'inin ev hanımı, \% 10'unun da serbest meslekte oldukları görülmüştür.

Tablo 5. Ankete Katılanların 15 Temmuz Darbe Girișiminin Yaşandığı Gece Sokağa Çıkıp Çıkmamalarına Göre Dağılımları

\begin{tabular}{lcc}
\hline & Frekans & $\%$ \\
\hline Evet & 258 & 51,6 \\
Hayır & 242 & 48,4 \\
\hline Toplam & 500 & 100 \\
\hline
\end{tabular}

Katılımcılara 15 Temmuz darbe girişiminin yaşandığı gece sokağa çıkıp çıkmadıkları sorulmuş ve \% 51,6'sı 15 Temmuz darbe girişiminin yaşandığı gece sokağa çıktığını, \% 48,4'ü ise çıkmadığını belirtmiştir.

Tablo 6. Ankete Katılanlara Göre Darbe Girişiminde İnsanların Sokağa Çıkmalarındaki En Önemli Unsur

\begin{tabular}{lcc}
\hline & Frekans & $\%$ \\
\hline Darbeye Karşı Olduğum İçin & 84 & 17 \\
Cumhurbaşkanının "Sokağa Çıkın” Çağrısı & 170 & 34 \\
Demokrasiye Sahip Çıkmak İçin & 55 & 11 \\
Vatan / Millet İçin & 177 & 35 \\
Diğer & 14 & 3 \\
\hline Toplam & 500 & 100 \\
\hline
\end{tabular}

İnsanların darbe girişiminin yaşandığı gece sokağa çıkma sebeplerini öğrenmek için sorulan soruya verilen cevaplara bakıldığında, katılımcıların \%17 si "darbeye karşı olduğum için”, \%34'ü "Cumhurbaşkanının sokağı çıkan çağrısı", \%11'i "demokrasiye sahip çıkmak için”, \% 35'i "vatan / millet için" ve \% 3'de "diğer" cevabını vermiştir.

Tablo 7. Ankete Katılanların Demokrasi Nöbetine Katılıp Katılmamalarına Göre Dağılımları

\begin{tabular}{lcc}
\hline & Frekans & $\%$ \\
\hline Evet & 362 & 72 \\
Hayır & 138 & 28 \\
\hline Toplam & 500 & 100 \\
\hline
\end{tabular}

Kendilerinin Demokrasi Nöbetlerine katılıp katılmadıklarını ortaya çıkarmaya çalışan soruya, katılımcıların \%72 'si evet cevabını, \% 28'i ise hayır cevabını vermiştir. Bu verilere göre araştırmaya katılanların büyük çoğunluğunun Demokrasi Nöbetlerine katıldığı görülmüştür.

Tablo 8. Ankete Katılanların İnsanların Demokrasi Nöbetlerine Katılmalarının Nedenine Yönelik Düșünceleri

\begin{tabular}{lcc}
\hline & Frekans & $\%$ \\
\hline Birlik / Beraberlik İçin & 157 & 43 \\
Darbe Tehlikesi Devam Ettiği İçin & 105 & 29 \\
Cumhurbaşkanının Daveti İle & 83 & 23 \\
Eğlenceli Bulduğum İçin & 12 & 3 \\
Diğer & 5 & 2 \\
\hline Toplam & 500 & 100 \\
\hline
\end{tabular}

İnsanların Demokrasi Nöbetlerine katılma nedenlerini öğrenmeye yönelik soruya katılımcıların \% 43’ü "birlik ve beraberlik için" , \% 29'u "darbe tehlikesi devam ettiği için", \% 23'ü de" Cumhurbaşkanının demokrasi nöbetine daveti", \%3'ü “eğlenceli bulduğum için" ve \% 2'si de diğer cevabını vermiştir.

Tablo 9. Ankete Katılanların Demokrasi Nöbetlerinden Neler Kazanıldığına Dair Görüşlerinin Dağılımı

\begin{tabular}{lcc}
\hline & Frekans & $\%$ \\
\hline Demokrasiye Olan İnancım Arttı & 29 & 6 \\
\hline Milli Birlik ve Beraberliğin Önemi & 161 & 32 \\
\hline $\begin{array}{l}\text { Tük Milletinin Zor Zamanlarda Bir Araya } \\
\text { Geldiğini Gördük }\end{array}$ & 204 & 41 \\
\hline Geleceğe Dair Umutlarım Arttı & 24 & 5 \\
\hline Diğer (Hiçbir Kazancı Olmamıştır) & 82 & 16 \\
\hline Toplam & 500 & 100 \\
\hline
\end{tabular}

Demokrasi Nöbetlerinin insanlara neler kazandırdığına yönelik sorulan soruya, katılımcıların \%6's1 "demokrasiye olan inancının arttı̆̆ı", \%32'si "birlik ve beraberliğin önemini anladıklarını”, \%41'i “Türk milletinin zor zamanlarda bir araya geldiğinin görüldügünü̈, \% 5'i “ geleceğe dair umutlarının arttığg” cevabını vermiştir. Katılımcıların \% 16'sının düşüncesine göre ise Demokrasi Nöbetlerinin topluma hiçbir katkısı olmamıştır.

Tablo 10. Ankete Katılanların Demokrasi Nöbetlerinin Amacına Ulaşıp Ulaşmadığı Yönündeki Düşüncelerine Göre Dağılımları

\begin{tabular}{lcc}
\hline & Frekans & $\%$ \\
\hline Evet & 414 & 83 \\
Hayır & 86 & 17 \\
\hline Toplam & 500 & 100 \\
\hline
\end{tabular}

Demokrasi Nöbetlerinin amacına ulaşıp ulaşmadığına yönelik soruya ise, araştırmaya katılanların \% 83'ü evet, \% 17'si ise hayır cevabını vermiştir. Genel olarak değerlendirildiğinde katılımcıların büyük çoğunluğunun Demokrasi Nöbetlerinin amacına ulaştığını düşündüğü ortaya çıkmıştır.

Tablo 11. Ankete Katılanların Demokrasi Nöbetlerinin Darbeye Karş1 Kamuoyu Oluşturup Oluşturmadığı Yönündeki Düşüncelerinin Dağılımları

\begin{tabular}{lcc}
\hline & Frekans & $\%$ \\
\hline Evet & 413 & 83 \\
Hayır & 87 & 17 \\
\hline Toplam & 500 & 100 \\
\hline
\end{tabular}

Katılımcılara Demokrasi Nöbetlerinin darbeye karşı kamuoyu oluşturup oluşturmadiğına yönelik sorulan soruya verdikleri cevaplarda, Demokrasi Nöbetlerinin \%83 ile darbeye karşı kamuoyu oluşturmada büyük oranda etkili olduğu görülmüştür.

Tablo 12. Ankete Katılanların Demokrasi Nöbetlerinin Yöneten Yönetilen Arasındaki İletişimi Etkileyip Etkilemediği Yönündeki Düşüncelerinin Dağılımları

\begin{tabular}{lcc}
\hline & Frekans & $\%$ \\
\hline Evet & 393 & 79 \\
Hayır & 107 & 21 \\
\hline Toplam & 500 & 100 \\
\hline
\end{tabular}

Araştırmaya katılanların \% 79’u Demokrasi Nöbetlerinin yöneten ile yönetilen arasındaki iletişimi olumlu etkilediğini, 
\% 21'inin ise etkilemediğini düşündükleri görülmüştür. Genel olarak bakıldığında Demokrasi Nöbetlerinin yöneten ve yönetilen arasındaki iletişimi kuvvetlendirdiğini söylemek mümkündür.

Tablo 13. Ankete Katılanların Demokrasi Nöbetlerinin Türk ve Dünya Kamuoyunda Oluşturduğu Algıya Yönelik Görüşlerinin Dăğlımı

\begin{tabular}{lcc}
\hline & Frekans & $\%$ \\
\hline Türkiye Birlik ve Beraberlik Mesajı Vermiştir & 149 & 30 \\
\hline $\begin{array}{l}\text { Türkiye'de Demokrasi Bilincinin Oluştuğu } \\
\text { Ortaya Çıkmışır }\end{array}$ & 16 & 3 \\
\hline $\begin{array}{l}\text { Türk İnsanının Devletine Sahip Çıktı̆̆ı- Vatanın } \\
\text { Sahipsiz Olmadığı Ortaya Çıkmıştır }\end{array}$ & 138 & 28 \\
\hline Hepsi & 134 & 27 \\
\hline Diğer (Herhangi Bir Algı Olmamıştır) & 63 & 12 \\
\hline Toplam & 500 & 100 \\
\hline
\end{tabular}

Katılımcılara Demokrasi Nöbetlerinin Türk ve dünya kamuoyunda nasıl bir algı oluşturduğunu ölçmek için sorulan anket sorusuna ankete katılanların \% 30 'u "Demokrasi Nöbetleri ile Türkiye'nin dünya kamuoyuna birlik ve beraberlik mesajı verdiği”, , \% 28'i “Türk insanının Demokrasi Nöbetleri ile devletine sahip çıktığını dünyaya gösterdiğini” belirtmiştir. Katılımcıların \%3'ü “Türkiye'de demokrasi bilincinin oluştuğunun ortaya çıktığını" savunurken, \%27'si ise bunların hepsinin ortaya çıktığını belirtmiştir. Demokrasi Nöbetleri ile dünya kamuoyunda herhangi bir algının oluşmadığı görüşünde olanların oranı ise $\% 12$ 'dir.

\section{Sonuç}

Siyasi alanda yöneticiler hem halkın nabzını tutmak hem de onlara daha iyi hizmet verebilmek için halkla ilişkilerden yararlanmaktadır. Seçim dışı ve seçim dönemlerinde sıkça başvurulan halkla ilişkiler çalışmaları kapsamında kamuoyu oluşturulmakta ya da oluşmuş kamuoyu değiştirilebilmektedir. Bu araştırma ile 15 Temmuz Darbe Girişimi sonrası başlayan ve uzun süre devam eden ve Demokrasi Nöbetleri diye adlandırılan toplantılar halkla ilişkilerin kamuoyu oluşturma özelliğgi kapsamında ele alınarak, yapılan anket çalışması ile tutulan Demokrasi Nöbetlerinin kamuoyunu ne yönde etkilediği halkla ilişkiler açısından ortaya konulmaya çalışılmış ve şu sonuçlara ulaşılmıştır:

Araştırmaya katılanların yarısından fazlası 15 Temmuz darbe girişiminin yaşandığı gece sokağa çıkmıştır (Tablo 5).Sokağa çıkanların dışarıya çıkma sebepleri büyük ölçüde vatana-millete sahip çıkma ve Cumhurbaşkanının yapmış olduğu çağriya uymaktır (Tablo 6). Bu verilerden yola çıkarak siyasal iletişimin en temel aktörlerinden biri olan liderin sürece ve halkla ilişkiler faaliyetlerine doğrudan katkısı olduğunu söylemek mümkündür.

Araştırmaya katılan 500 kişinin \%75 e yakını Demokrasi Nöbetlerine katılmıştır (Tablo 7). Katılımcıların Demokrasi Nöbetine katılma nedenlerinin başında birlik ve beraberlik mesajı vermek gelmektedir. Bunun dışında sırasıyla darbe tehlikesinin devam etmesi, Cumhurbaşkanının Demokrasi Nöbetlerine daveti ve bu organizasyonu eğlenceli bulmaları Demokrasi Nöbetlerine katılma nedenleri içinde gösterilmiştir (Tablo 8).
Katılımcılara göre Demokrasi Nöbetleri ile birlikte Türk insanının ne kadar farklı düşüncelerden oluşsa da zor zamanlarda bir araya geldiğinin görüldüğü ortaya çıkmıştır. Ayrıca birlik ve beraberliğin ne kadar önemli olduğu anlaşılmıştır. Katılımcıların \% 16'sının düşüncesine göre ise Demokrasi Nöbetlerinin topluma hiçbir kazancı olmamıştır (Tablo 9).

Katılımcıların büyük çoğunluğunun Demokrasi Nöbetlerinin amacına ulaştığını düşündüğü ortaya çıkmıştır (Tablo 10). Ayrıca Demokrasi Nöbetleri yöneten ile yönetilenler arasındaki iletişimi olumlu yönde etkilemiş ve kuvvetlendirmiştir (Tablo 12).

Araştırma sonuçlarına göre Demokrasi Nöbetlerinin darbeye karşı kamuoyu oluşturmada büyük oranda etkili olduğu tespit edilmiştir (Tablo 11). Ayrıca araştırmaya katılanların çoğunluğu Demokrasi Nöbetleri ile Türk ve dünya kamuoyunda "Türk insanının zor zamanlarda beraber olduğu ve devletine sahip çıktığı algısı oluşturulduğunu düşünmektedir. Demokrasi Nöbetlerinin Türk ve Dünya kamuoyunu etkilemediğini düşünenlerin oranı ise \%12'dir (Tablo 13).

Genel olarak bakıldığında araştırmada 15 Temmuz darbe girişimi sonrasında yapılan Demokrasi Nöbetlerinin halkı ortak noktalarda birleştirerek darbeye karşı bir kamuoyu oluşturduğu, yöneten ve yönetilenler arasındaki iletişimi güçlendirerek, yurt içinde ve yurt dışında birlik ve beraberlik mesajı verildiği hipotezi doğrulanmıştır. Araştırmanın hipotezleri içerisinde olmasa da elde edilen verilerden Demokrasi Nöbetlerinde siyasal aktörlerden devlet başkanının siyasal iletişim ve halkla ilişkiler kapsamında kamuoyunu etkilemede ne kadar önemli olduğu da ortaya konulmuştur. Çünkü elde edilen veriler insanların sokağa çıkmasında ve bu nöbetlere katılmasında devlet başkanının etkisinin büyük olduğunu göstermektedir (Tablo 6-7). 15 Temmuz Darbe Girişimi sonrası özellikle iktidarın kamuoyunu etkileme ve oluşturmasında Demokrasi Nöbetlerini önemli bir halkla ilişkiler çalışması olarak değerlendirmek mümkündür.

\section{Kaynakça}

Atik, A., \& Taşcioğlu, R. (2012). Radyo ve Televizyonun Yerel Yönetimlerin Halkla İlişkiler Uygulamalarında İletişim Yöntem ve Aracı Olarak Kullanımı: Erzurum Belediyeleri Örneği. Uluslararası Yönetim İktisat ve Işletme Dergisi, 5(10), 159-170.

Bayer, S. (2009). Tanitma Politikalarında Bir Propaganda Aracı Olarak Sinema. Yüksek Lisans Tezi. Ankara: Kültür Ve Turizm Bakanlığı.

Bektaş, A. (2007). Kamuoyu, Illetişim ve Demokrasi. Ankara: Bağla Yayıncılık.

Bianet (2016). KONDA Demokrasi Nöbetlerine Katılanların Profilini Araştırdı. (Erişim: 14.06.2017), http://bianet.org/bianet/toplum/177656-kondademokrasi-nobetlerine-katilanlarin-profilini-arastirdi

Çağlar, N. G. (2006). Üniversite Kütüphanelerinde Halkla Ilişkiler ve Başkent Üniversitesi Kütüphanesi. Yüksek Lisans Tezi. Ankara: Hacettepe Üniversitesi. 
Demir, Ş. Ş. (2011). Halkla ilişkiler faaliyetlerinde iletişim tekniklerinin etkisi: Konaklama işletmeleri örneği. Uluslararasi Insan Bilimleri Dergisi, 8(2), 127-150.

Demirtaş, E. (2010). AKP'nin 29 Mart 2009 Yerel Seçimlerinde Uyguladı̆̆ Siyasal İletişim Faaliyetleri: Diyarbakır Örneği. Yüksek Lisans Tezi. Ankara: Gazi Üniversitesi.

Devran, Y. (2004). Siyasal Kampanya Yönetimi. İstanbul: Odak İletişim.

Froehlich, R., \&, Rüdiger, B. (2006). Framing Political Public Relations: Measuring Success Of Political Communication Strategies İn Germany. Public Relations Review, 32, 18-25.

Greyser, S. (1986). Research-Management Partnership Proves Best, Advertising Age, 34.

Harris, A., Garramone, G., Pizante, G., \& Komiya, M. (1985). Computers İn Constituent Communications, Public Relations Repjew, 11, 34-39.

Kahveci, Erol, (2017). Rapor. (Erişim: 14.06.2017), https://www.asbu.edu.tr/media/default/duyurular/prof_d r_erol_kahveci_rapor.pdf

Kalçık, T. (2007). Televizyonda Siyasal Propaganda Ve Akp. Yüksek Lisans Tezi. Ankara: Ankara Üniversitesi.

Kiousisa,S., Kimb, J. Y., Carnifaxa, A.C., \& Kochhara, S. (2014). Exploring The Role Of The Senate Majority Leader's Political Public Relations Efforts. Public Relations Review, 40, 615-617.

Krejcie R. \& Morgan D. (1970). Determining Sample Size for Research Activities. Educational and Psychological Measurement, 30, 607-610.

Toledano, M. (2017). Emergent methods: Using netnography in public relations research. Public Relations Review, 43(3), 597-604.

Oktay, M. (2002). Politikada Halkla İlişkiler. İstanbul: Derin Yayınları.

Onat, F. (2010). Bir Halkla İlişkiler Uygulama Alanı Olarak Sosyal Medya Kullanımı: Sivil Toplum Örgütleri Üzerine Bir İnceleme. İletişim Kuram Ve Araştırma Dergisi, 31, 103-122.

Özüpek N. M. (2003). Halkla İlişkiler Faaliyetleri ve Basın. Selçuk İletişim, 2(4), 84-89.

Page, T. G., \& Adams, E. (2014). Public relations tactics and methods in early 1800s America: An examination of an American anti-slavery movement. Public Relations Review, 40(4), 684-691.

Painter D. L. (2015). Reviewonline Political Public Relations And Trust: Source Andinteractivity Effects İn The 2012 U.S. Presidential Campaign. Public Relations Review, 41, 801-808.

Peltekoğlu, B. F. (2001). Halkla İlişkiler Nedir?. İstanbul: Beta Basım.

Petrison, L.A., \& Wang, P. (1993). From Relationships To Relationship Marketing: Applying Database Technology To Public Relations. Public Relations Review 19, 235245.
Ramsey, S.A. (1993). Qsues Management And The Use Of Technologies İn Public Relations. Public Iwahs Reviev, 19, 261-275.

Süllü, Z. (2010). Siyasal Halkla İlişkiler Sürecinde Hesabı Verilebilirlik. Selçuk İletişim, 6(3), 216-228.

Strömbäck, J., \& Kiousis, S. (2011). Political Public Relations: Principles and Applications. New York: Taylor \& Francis.

Tomić, Z., \& Grbavac, I. (2016). Political Public RelationsMedia and Information Management. Communication Management Review, 1(01), 84-102.

Ustakara, F. (2011). Halkla İlişkiler ve Psikoloji İlişkisi Üzerine. Gümüşhane Üniversitesi Illetişim Fakültesi Elektronik Dergisi, 1, 170-185.

Uztuğ, F. (2004). Siyasal İletişim Yönetimi. İstanbul: Mediacat Yayınları.

Verčič, D., Verčič, A. T., \& Sriramesh, K. (2015). Looking for digital in public relations. Public Relations Review, 41(2), 142-152.

Weaver, R. A., \& Glasser, T. L. (1984). Survey research for legislative relations. Public Relations Review, 10(2), 3948. 